\title{
Factors affecting in-stent restenosis and the role of flow-mediated dilatation
}

\section{Stent restenozuna etki eden faktörler ve akım aracılı dilatasyonun rolü}

\author{
Gökhan Bektașoğlü ${ }^{1}$ Zeki Dogan¹, Ahmet Yillmaz²
}

'Department of Cardiology, Atlas University Faculty of Medicine, İstanbul, Turkey.

${ }^{2}$ Department of Cardiology, Sivas Cumhuriyet University Faculty of Medicine, Sivas, Turkey

Corresponding author: Gökhan Bektaşoğlu, MD, ${ }^{1}$ Department of Cardiology, Atlas University Faculty of Medicine, İstanbul, Turkey,

E-mail: bektasoglu@yahoo.com

Received/Accepted: February 06, 2021 /September 25, 2021

Conflict of interest: There is not a conflict of interest.

\section{SUMMARY}

Objective: In-stent restenosis is a major problem concerning percutaneous coronary interventions. Brachial artery flow-mediated dilation, a noninvasive indicator of endothelial dysfunction, and its relationship with future cardiovascular events is well known.

The aim of this study was to identify factors thought to have an effect on instent restenosis and to test the predictive value of flow-mediated dilatation. Method: 74 consecutive patients who were treated with bare-metal stents and recommended control coronary angiography during their follow-up were included into the study. Patients were categorized into 2 groups in the form of those having in-stent restenosis $(n=35)$ and no in-stent restenosis $(n=39)$. Clinical, biochemical, angiographic parameters and also flowmediated dilatation was evaluated.

Results: Flow-mediated dilatation was significantly impaired in patients with in-stent restenosis than in patients with no in-stent restenosis $(5.1(4.8)$ $\%$ vs. 9.2(4.1) \%, p<0.001). After multivariable analysis; flow-mediated dilatation $(\mathrm{p}=0.004)$, stent diameter $(\mathrm{p}=0.014)$, stent length $(\mathrm{p}=0.01)$, no use of statins $(\mathrm{p}=0.017)$ and absence of TIMI-3 flow $(\mathrm{p}=0.039)$ were found as independent predictors of in-stent restenosis. According to the receiveroperating characteristic curve analysis, optimal cut-off value of flowmediated dilatation to predict in-stent restenosis was measured to be $\leq 6.8 \%$, with $75.8 \%$ sensitivity and $78.8 \%$ specificity (Area under curve $0.764,95 \%$ confidence interval 0.644-0.885).

Conclusions: Our study suggested that flow-mediated dilatation may contribute to the identification of high-risk patients who will develop instent restenosis after percutaneous coronary interventions.

Keywords: Stent, restenosis, flow-mediated dilatation.
ORCID IDs of the authors: G.B. 0000-0002-4571-7908 Z.D. 0000-0002-5620-7268 A.Y. 0000-0002-9832-8981 olmayan bir göstergesi olan brakiyal arterin akım aracılı dilatasyonu ve bunun gelecekteki kardiyovasküler olaylar ile ilișkisi iyi bilinmektedir. 
Yöntem: Çılak metal stent ile tedavi edilmiș ve takiplerinde kontrol koroner anjiyografï önerilen 74 ardışık hasta çalışmaya dahil edildi. Hastalar stent restenozu olanlar $(n=35)$ ve stent restenozu olmayanlar $(n=39)$ şeklinde 2 gruba ayrıldı. Klinik, biyokimyasal, anjiyografik parametreler ve akım aracılı dilatasyon değerlendirildi.

Bulgular: Stent restenozu olan hastalarda, stent restenozu olmayan hastalara göre akım aracilı dilatasyonun önemli ölçüde bozulmuş olduğu görüldü (\% 5.1 (4.8) vs.\% 9.2 (4.1), P <0.001). Çok değişkenli analizden sonra; akım aracılı dilatasyon ( $p=0,004)$, stent çapı ( $p=0,014)$, stent uzunluğu $(p=0,01)$, statin kullanmamak $(p=0,017)$ ve TIMI-3 akım yokluğu $(p=0,039)$ stent restenozunun bağımsız prediktörleri olarak bulundu. Alıcı işletim karakteristiği eğrisi analizine göre, stent içi restenozu tahmin etmek için akım aracılı dilatasyonun optimal kesme değeri, \% 75.8 duyarlılık ve\% 78.8 özgüllük ile $\leq \% \quad 6.8$ olarak ölçülmüştür (Eğri altındaki alan $0.764, \quad \% \quad 95$ güven aralığ $0.644-0.885$ ). Sonuç: Çalışmamız, perkütan koroner girişimler sonrası stent restenozu gelişecek yükssek riskli hastaların belirlenmesine akım aracılı dilatasyonun katkı sağlayabileceğini düşündürmektedir.

Anahtar sözcükler: Stent, restenoz, akım aracılı dilatasyon.

\section{INTRODUCTION}

Atherosclerotic cardiovascular disorders remain as a major health problem all over the world. It is the world' $s$ leading cause of morbidity and mortality 1,2 .

The risk factors that cause atherosclerosis and the pathophysiology of the disease is well known, but not a single specific factor that initiates the disease has been identified. Today, atherosclerosis has been considered as a chronic disease that lasts for decades with the interaction of genetic and environmental factors. Endothelial dysfunction is known to have accompanied this process since the early stages 3,4 . Brachial artery flow-mediated dilation (FMD) is a non-invasive indicator of endothelial dysfunction and is widely used in clinical trials for this purpose ${ }^{5}$. Its relationship with future cardiovascular events has been shown in various studies ${ }^{6-9}$.

Percutaneous coronary intervention (PCI) with stent implantation have been widely applied for nearly 30 years in the treatment of atherosclerotic coronary artery disease (CAD). PCI techniques brought along with additional problems. Restenosis, which is defined as the development of stenosis again within the same coronary segment, is a common problem after percutaneous transluminal coronary angioplasty (PTCA) and coronary stent implantations. As a result of studies aimed at identifying restenosis mechanisms and the factors that cause it, drug-eluting stents (DES) have been used to reduce the proliferative response seen in the endothelium. Despite all these improvements, restenosis rates are still high.

The aim of this study was to identify clinical and angiographic factors thought to have an effect on in-stent restenosis (ISR) and to test the predictive value of FMD.

\section{MATERIAL AND METHODS}

\section{Study population}

Patients who were treated with bare-metal stent (BMS) and recommended control coronary angiography (CA) during their follow-up were included into the study. The study was carried out in "Cumhuriyet University Faculty of Medicine Hospital" for two years. Written informed consent was obtained from all participants and the study was conducted in accordance with the ethical principles outlined in the declaration of Helsinki (1964). Baseline characteristics and medications of the 74 consecutive patients were recorded in detail. The presence of metabolic syndrome in patients was evaluated according to NCEP ATP III criteria ${ }^{10}$. Existence of angina pectoris (AP) during followup was asked and recorded. A blood sample was taken from all patients in the morning following one night of fasting. Total cholesterol, triglycerides, LDL cholesterol, HDL cholesterol and fasting blood glucose were studied in blood samples.

The files of the patients were examined in detail. Patients with significant elevation in cardiac enzymes (Troponin-I and Ck-MB >3 times) taken after PCI were accepted as PCI-related myocardial infarction and excluded from the study ${ }^{11}$. G IIbIIIa inhibitors, if used was recorded. The left ventricle ejection fraction (LVEF) was recorded by examining the echocardiography reports in the patients' file. Patients without echocardiography reports, estimated LVEF values were given by an experienced invasive cardiologist who evaluated left ventriculography recordings.

\section{Evaluation of CA and PCI}

All CA and PCI procedures were performed in Toshiba and Philips angiography device by interventional cardiologists with $\geq 75$ intervention experience per year, using standard methods. Former CA recordings were gathered from the archive and reference vessel diameter, lesion type, TIMI flow after the procedure, dissection 
developed in the procedure, presence of residual stenosis was evaluated and Gensini scores were calculated. The diameter and length of the stent, balloon diameter and length if used, were recorded by examining the PCI reports in the patients' file. Coronary angiographic parameters were evaluated by an experienced invasive cardiologist, the presence of $>50 \%$ stenosis observed in the stent and near $5 \mathrm{~mm}$ of the stent ends was considered as ISR.

TIMI flow classification was used to evaluate the coronary flow after the stent implantation ${ }^{12}$. According to this class, lesions were planned to be divided into 4 groups. However, since TIMI 0 and 1 flow were not observed in any of the patients, the patients were grouped as having TIMI 3 flow or not.

Gensini score was used to calculate the prevalence and severity of coronary artery disease in patients ${ }^{13-14}$. According to this system, the coronary tree was divided into 11 sections and points were given according to the degree of stenosis; 1 point for stenosis between $0-25 \%, 2$ points for stenosis between $25-50 \%, 4$ points for stenosis between $50-75 \%, 8$ points for stenosis between $75-90 \%, 16$ points for stenosis between $90-99 \%, 32$ points for total occlusion. The scores given for stenosis were multiplied by the coefficients based on the segment where coronary stenosis was found, and the scores were collected and Gensini score was calculated.

Ellis modification of the AHA/ACC lesion classification system was used to classify stent implanted lesions ${ }^{15}$. According to this classification, lesions were separated into 4 classes; type A, type B1, type B2 and type C.

\section{Evaluation of Flow-mediated dilatation}

Drugs (antihypertensive drugs, statins and nitrates etc.) that are thought to affect the outcome were discontinued at least 4 times the half-life of the drug before the evaluation of FMD 5 . Measurements were carried out using 10L transducer (4.0-10.0 MHz) with Vivid 4 Cardiovascular Ultrasound System. Patients were studied supine at room temperature $\left(25^{\circ} \mathrm{C}\right)$ and at rest for 5-10 minutes before the evaluation, smoking and beverages that contained caffeine were prohibited within the preceding 12 hours. The trace of the left brachial artery was evaluated with B-mode echocardiography, the area where the best image was taken on the patient's arm was marked with a pen and the baseline brachial artery diameter (BAD) was measured at end-diastole. Electrocardiogram (ECG)-gated analysis was used to determine end diastolic BAD (diameter at the onset of R-wave). In the BAD measurements, the length between the anterior and posterior arterial wall intima was taken into account. In order to optimally evaluate the intimal region, operator zoomed into the relevant segment. Then cuff of the sphygmomanometer placed over the antecubital fossa was inflated to $50 \mathrm{mmHg}$ above systolic artery pressure for 5 minutes to form ischemia in the brachial artery. After the cuff was deflated, the hyperemia phase was evaluated with PW doppler and trace of the brachial artery was examined continuously for 3 minutes after deflation. Brachial artery trace was recorded for at least 3 cycles of heart beat in every 20-30 seconds. Maximal BAD measured after deflation was used for determining FMD. During the procedure, care was taken to keep the patient's arm in the same position. FMD was evaluated as percentage of the difference between the two diameter measurements to baseline BAD ratio ${ }^{5}$.

FMD $(\%)=[($ Maximum BAD after hyperemia Baseline BAD) / Baseline BAD] X 100

\section{Statistical Analysis}

Continuous variables are expressed as mean (SD) and categorical variables as percentages. Patients were categorized into 2 groups in the form of those having in-stent restenosis (ISR) and no in-stent restenosis (no ISR). Patients were included in the restenosis group in case of ISR in any of the stents implanted. Comparisons between groups of patients were performed using chi-square tests for categorical variables, 2-tailed independent-samples $t$ test for normally distributed continuous variables, and Mann-Whitney U tests when the distribution was skewed. Variables found to be statistically significant on univariate analysis were used in multivariable logistic regression analysis. Multivariable logistic regression analysis was carried out using backward-stepwise method. In this way, logistic regression analysis was carried out on 74 patients. The appropriateness of the model created was assessed using the Hosmel and Lemeshow test $(\mathrm{p}=0.38)$. Receiver-operating characteristic (ROC) curve analysis was performed to identify the optimal cut-off point of FMD (at which sensitivity and specificity would be maximal) for the prediction of ISR. Area under the curve (AUC) was calculated as measure of the accuracy of the test. Kaplan-Meier method with a log-rank test was used to show the event-free survival in two patient subgroups, based on a cut off value. All statistical procedures were performed using SPSS version 16.0 (SPSS, Inc., Chicago, Illinois). A $\mathrm{p}$ value $<0.05$ was considered statistically significant. 


\section{RESULTS}

\section{Clinical and Demographic Characteristics of Patients}

The mean age of the patients was 57.5 (10.0) years (52\% women, $48 \%$ men). Control angiography of patients was performed at the earliest in the 2nd month and at the latest in the 48th month (mean 13(9.5)). ISR was observed in 35 patients (47.3\%).

Clinical and demographic characteristics of patients with restenosis and no restenosis are shown in table 1 . There was no statistically significant difference between the 2 groups regarding age, gender, hypertension, hyperlipidemia, family history of CAD, smoking status, history of myocardial infarction, presence of metabolic syndrome, body mass index and LVEF (table 1). Presence of DM was more prevalent among ISR group than no ISR group $(40.0 \%$ and $12.8 \%, \mathrm{p}=0.008$, respectively). AP during followup was significantly higher in ISR group than in no ISR group $(71.4 \%$ and $43.6 \%, \mathrm{p}=0.02$, respectively).

Statin use was higher among patients with no ISR (87.2\% and $65.7 \%, p=0.02$, respectively). ACE inhibitor or Angiotensin Receptor Blocker (ARB) use was also higher among patients with no ISR (89.7\% and $68.6 \%, \mathrm{p}=0.02$, respectively). Other medications including calcium channel blockers, acetyl salicylic acid, $\beta$-Blocker, oral nitrate, clopidogrel and diuretic use were similar between groups (table 1). Glycoprotein IIb/IIIa inhibitor use after PCI was also similar in ISR and no ISR group ( $22.9 \%$ and $17.9 \%, \mathrm{p}=0.60$, respectively)

HDL cholesterol level was lower in the ISR group compared to the no ISR group (32.2(9.3) and 37.0(10.9), $\mathrm{p}=0.047$, respectively), other lipid parameters were similar between groups. Total cholesterol $(\mathrm{p}=0.78)$, LDL cholesterol $(\mathrm{p}=0.54)$ and triglyceride levels $(\mathrm{p}=0.69)$ were similar in no ISR and ISR groups.

Comparison of groups according to the Gensini score and control CA time were also found to be statistically insignificant $(\mathrm{p}=0.87$ and $\mathrm{p}=0.15$, respectively). FMD was significantly lower in ISR group than in no ISR group (5.1(4.8) \% and 9.2(4.1) \%, respectively, $\mathrm{p}<0.001)$.

\section{Angiographic and Procedural Features of Stent Implanted Lesions}

A total of 94 lesions of 74 patients were treated with stent implantation. The number of stents per patient was calculated as 1.27. Angiographic and procedural features of lesions according to the presence and absence of restenosis are shown in table 2.

Reference vessel diameter $(3.07(0.47) \mathrm{mm}$ vs. 2.77(0.42) $\mathrm{mm}, \mathrm{p}=0.002)$ and stent diameter $(3.08(0,48) \mathrm{mm}$ vs. $2.83(0.42) \mathrm{mm}, \mathrm{p}=0.009)$ were smaller, stent length (15.35(4.89) $\mathrm{mm}$ vs. $17.70(6.12) \mathrm{mm}, \mathrm{p}=0.04)$ was longer in ISR group than in no ISR group. Other procedural characteristics; pre-dilatation, pre-dilatation balloon diameter and length, presence of dissection in PCI, and target vessel were found to be statistically insignificant between groups (table 2).

In the group where restenosis was not observed, the presence of TIMI 3 flow after the stent was significantly higher than in the group with restenosis $(89.8 \%$ and $71.1 \%, \quad \mathrm{p}=0.02$, respectively).

Statistically significant differences were observed between ISR and no ISR group in terms of lesion types $(\mathrm{p}=0.003)$. The main reason for the difference between groups was the lower incidence of Type A lesions in the ISR group.

\section{Logistic Regression Analysis}

The presence of DM, angina during follow-up, FMD, absence of TIMI 3 flow after stent implantation, stent diameter, stent length, HDL cholesterol, no use of statin and ACE inhibitor/ARB were included in logistic regression analysis and evaluated by backward-stepwise method. The reason that makes difference between groups according to the lesion types was the presence of only one type A lesion in restenosis group. This might affect the results, so it wasn't included in the logistic regression analysis. After multivariable analysis; FMD, stent diameter, stent length, no use of statins and absence of TIMI 3 flow were found as independent predictors of restenosis that may develop in the future. Multivariable analysis results are shown in table 3 . 
Table 1: Clinical and demographic characteristics of the patients

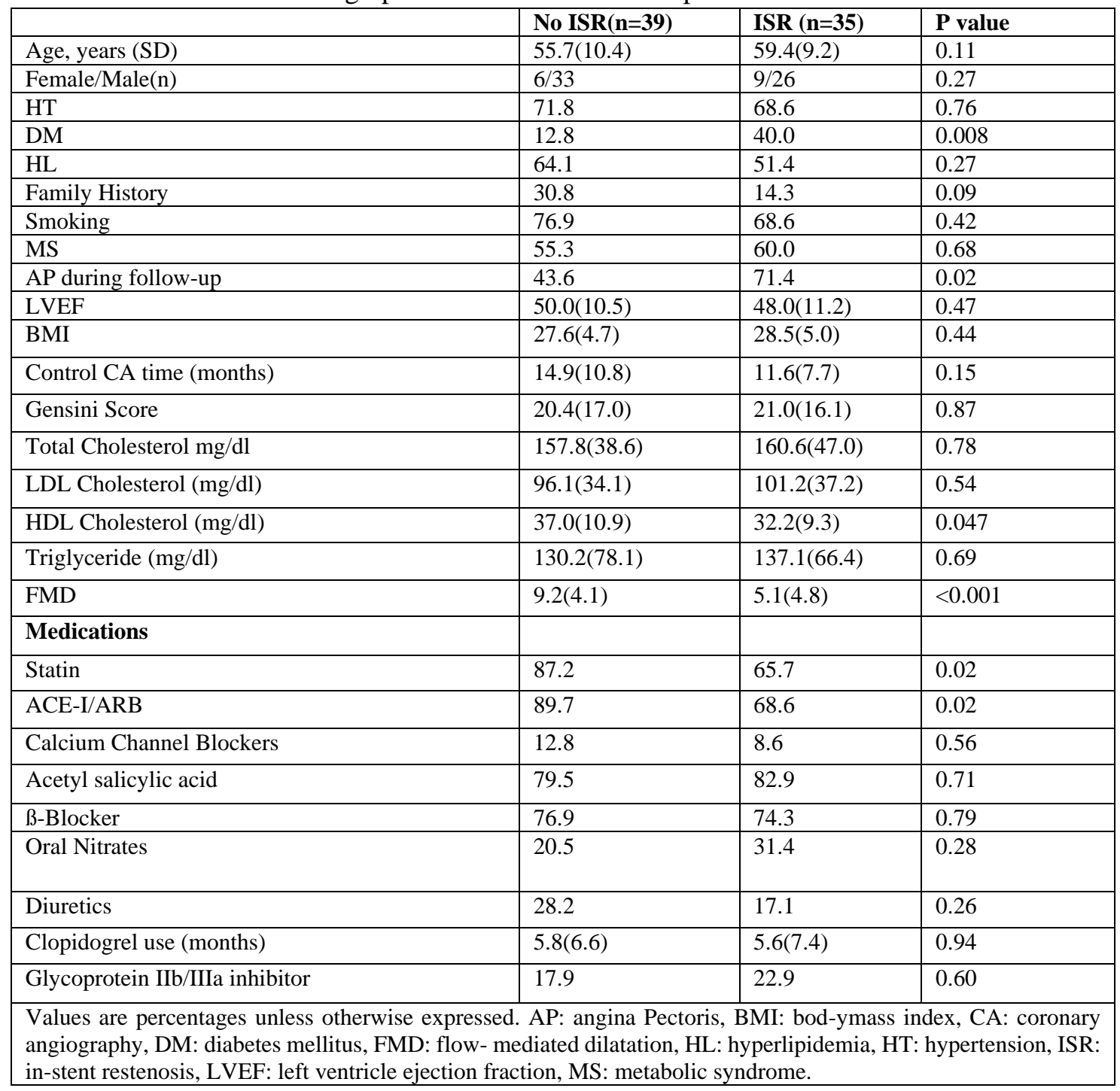

Table 2: Angiographic and lesion characteristics of the patients

\begin{tabular}{|c|c|c|c|}
\hline & No ISR $(n=49)$ & ISR (n=45) & P value \\
\hline Reference Vessel Diameter (mm) & $3.07(0.47)$ & $2.77(0.42)$ & 0.002 \\
\hline Stent Diameter $(\mathrm{mm})$ & $3.08(0.48)$ & $2.83(0.42)$ & 0.009 \\
\hline Stent Length (mm) & $15.35(4.89)$ & $17.70(6.12)$ & 0.04 \\
\hline Pre-dilatation & 46.9 & 53.3 & 0.54 \\
\hline Balloon Diameter (mm) & $2.70(0.49)$ & $2.62(0.45)$ & 0.61 \\
\hline Balloon Length (mm) & $14.96(3.65)$ & $15.67(3.62)$ & 0.51 \\
\hline TIMI 3 Flow & 89.8 & 71.1 & 0.02 \\
\hline Dissection in PCI & 2.0 & 8.9 & 0.14 \\
\hline \multicolumn{4}{|l|}{ Lesion Type n (\%) } \\
\hline A & $11(22.4)$ & $1(2.2)$ & \multirow{4}{*}{0.003} \\
\hline B1 & $26(53.1)$ & $19(42.2)$ & \\
\hline B2 & $10(20.4)$ & $20(44.4)$ & \\
\hline $\mathrm{C}$ & $2(4.1)$ & $5(11.1)$ & \\
\hline \multicolumn{4}{|l|}{ Target Vessel n (\%) } \\
\hline LAD & $13(26.5)$ & $22(48.9)$ & \multirow{5}{*}{0.19} \\
\hline Diagonal & $2(4.1)$ & $1(2.2)$ & \\
\hline Circumflex & $12(24.5)$ & $6(13.3)$ & \\
\hline $\mathrm{OM}$ & $5(10.2)$ & $2(4.4)$ & \\
\hline RCA & $17(34.7)$ & $14(31.1)$ & \\
\hline
\end{tabular}


Table 3: Multivariate logistic regression analysis. Variables associated with ISR.

\begin{tabular}{|l|l|l|l|l|l|}
\hline & B & Wald & $\operatorname{Exp}(\mathbf{B})$ & P & $\operatorname{Exp(B)~95\% ~CI~}$ \\
\hline Stent Diameter & -1.95 & 5.98 & 0.14 & 0,01 & $0.03-0.68$ \\
\hline Stent Length & 0.16 & 6.70 & 1.18 & 0,01 & $1.040-1.33$ \\
\hline Absence of TIMI 3 flow & 1.73 & 4.25 & 5.63 & 0,04 & $1.09-29.08$ \\
\hline FMD & -0.20 & 8.22 & 0.82 & 0.004 & $0.72-0.94$ \\
\hline No use of Statins & 1.93 & 5.75 & 6.90 & 0.02 & $1.42-33.51$ \\
\hline Constant & 3.48 & 2.48 & 32.47 & & \\
\hline ISR: in-stent Restenosis, FMD: flow-mediated dilatation, CI: confidence interval. \\
\hline
\end{tabular}

\section{ROC Curve and Kaplan Meier Analysis}

According to the ROC curve analysis, the optimal cut-off value of FMD to predict ISR was measured to be lower than $6.8 \%$, with $75.8 \%$ sensitivity and
$78.8 \%$ specificity (AUC $0.764,95 \%$ CI $0.644-$ 0.885 , Figure 1). Kaplan Meier analysis showed lower ISR-free survival during follow-up in patients with FMD $\leq 6.8 \%$ ( $<<0.001$, Figure 2$)$.

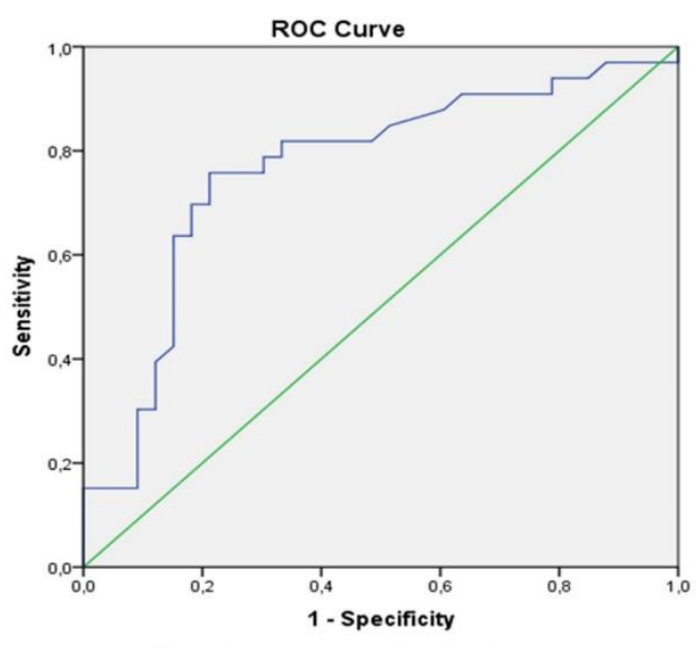

Diagonal segments are produced by ties

Figure 1: ROC Curve of FMD to predict in-stent restenosis (AUC-0.764, 95\%CI 0.644-0.885).

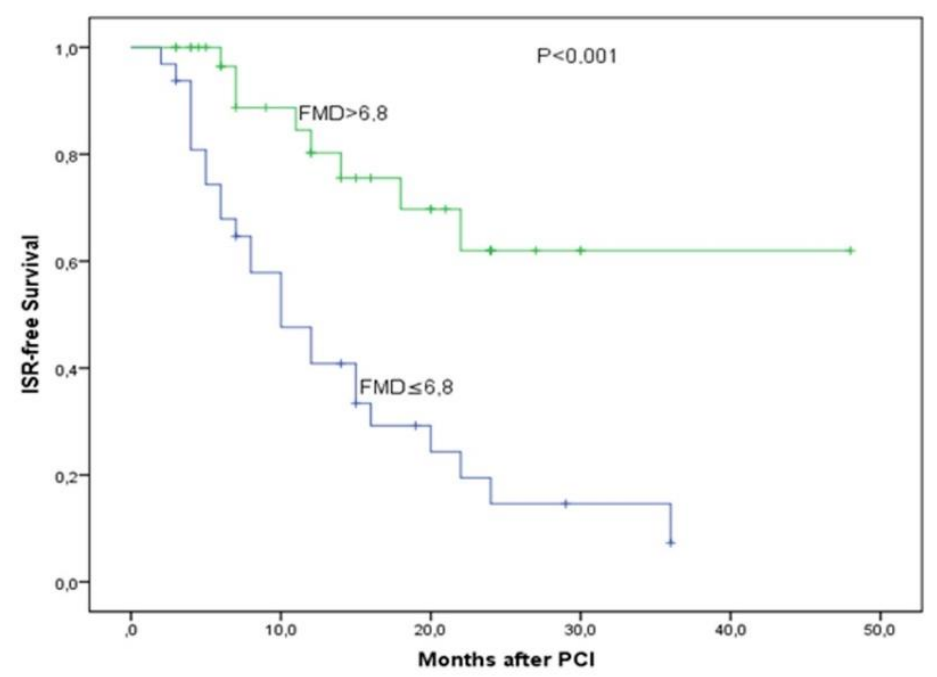

Figure 2: ISR-free survival curves in patients with FMD above or below cut-off value. 


\section{DISCUSSION}

The importance of endothelial dysfunction is well known in the development and progression of atherosclerosis. Endothelial dysfunction, characterized by; vasospasm, vasoconstriction, disorders in the coagulation and fibrinolytic mechanism, expression of adhesion molecules, increased synthesis of proinflammatory factors, increased oxidative stress and effects on smooth muscle cell proliferation, occurs in the early stages of the atherosclerotic process. It is known to contribute; formation, progression and complications of atherosclerotic plaques ${ }^{16-20}$. FMD measured in the brachial artery is known to be closely related to coronary endothelial dysfunction ${ }^{21}$. The method is frequently used in studies because it is non-invasive, easy to apply and repeat. Furthermore, brachial artery FMD has been shown to be a predictor of future cardiovascular events ${ }^{6-}$ ${ }^{9,22}$. However, the number of studies assessing the effect of impaired endothelial dysfunction on restenosis is limited ${ }^{23-24}$.

Studies have shown that endothelial dysfunction contributes to the proliferation and migration of smooth muscle cells, while nitric oxide released from the robust endothelium is involved in preventing smooth muscle cell growth ${ }^{25,27}$. Considering that smooth muscle cell proliferation is an important pathophysiological mechanism in the development of neointimal hyperplasia causing ISR, it is not surprising that FMD, an indicator of endothelial dysfunction, is an independent predictor for ISR.

Due to various clinical, angiographic and PCI related factors, ISR have been reported both in BMS and DES (10.3\% vs 5.3\%, respectively) ${ }^{28}$. In high-risk patients ISR rates increased up to $40 \%$ and $20 \%$ for both BMS and DES. Therefore, determination of patients with high risk for ISR can make significant contributions in directing clinical follow-up and treatment. Similar to the results of previous studies ${ }^{23,24}$, our study showed the role of FMD in predicting ISR. In a previous study which evaluated FMD measurement at one month after PCI had shown predictive value of FMD at sixth month follow-up ${ }^{23}$. Another study had also shown predictive value of FMD measured at sixth month after PCI, however in that study FMD measurement before PCI had failed to predict ISR ${ }^{24}$. Given the fact that endothelial dysfunction is an ongoing process and medications used (statins, ACE-I/ARB etc.), exercise and lifestyle changes after PCI may also improve endothelial functions, we think early measurement of FMD is not reasonable. In our study FMD was measured before control CA (13(9.5) months), which also reflects late restenosis. In contemporary DES era, we think timing of FMD measurement becomes more important. However, this assumption and also the predictive value of FMD after DES implantation needs further evaluation. A previous study evaluated FMD in DES implanted patients ${ }^{29}$. In this study FMD was measured one week after PCI and primary endpoint of this study included cardiac death, nonfatal myocardial infarction, stroke, coronary revascularization, and critical limb ischemia. FMD was found as the sole factor for predicting future cardiovascular events, explained with above mentioned factors, after multivariable analysis. However, ISR rates were similar between groups. Authors explained this finding with relatively small size of the study population ( 9 patients out of 80 had ISR). Although DES interfere with restenosis mechanisms and expected restenosis rates are lower, there are still group of patients who had higher restenosis rates according to their clinical and complex lesion characteristics (DM, bifurcation lesions etc.). Evaluation the predictive value of FMD in this high-risk group of patients needs further evaluation. We think, FMD will provide significant benefits during clinical follow-up of this high-risk patients.

In multivariable analyses; Similar to earlier studies, stent diameter, stent length and absence of TIMI III flow were found as independent predictors for restenosis ${ }^{25-26}$. Although the presence of DM in our study was found to be a significant indicator of restenosis in univariate analyses, the meaning of it was lost in multivariable analysis. This can be explained by the small number of diabetic patients enrolled in our study.

Another important finding of our study was significantly less observed ISR rates in patients taking statins, regardless of their total cholesterol, LDL cholesterol and triglyceride levels. This finding was similar with previous studies. In a study of 341 patients, restenosis rates were lower in patients taking statins regardless of LDL cholesterol levels and percentage of decline in LDL cholesterol ${ }^{30}$. Lower ISR rates, seen in patients under statin treatment irrespective of cholesterol levels, can be explained by the pleiotropic properties of statins. As a matter of fact, the healing effects of statins on endothelial functions have also been demonstrated by various studies ${ }^{31-33}$. Studies have also shown that statins prevent the proliferation of vascular smooth muscle cells and induce apoptosis ${ }^{35-36}$. Due to these positive effects, all patients should be given statins regardless of cholesterol levels after PCI. 


\section{Limitations}

Control CA was not performed to all stent implanted patients during the study period, only patients to whom control CA was recommended because of any clinical indication during their follow-up were included into the study. Hence, ISR rates seemed relatively high. Selection-bias might have influenced our results; therefore, findings of this study cannot be extrapolated to all stent implanted patients. The number of diabetic patients were less and it was conducted with relatively small number of patients. Only BMS implanted patients were evaluated in this study, therefore above-mentioned findings cannot be generalized to DES implanted patients.

\section{CONCLUSION}

Our study suggested that brachial artery FMD, stent diameter, stent length, no use of statins and absence of TIMI 3 flow were independent predictors of ISR. FMD may contribute to the identification of high-risk patients who will develop ISR after BMS implantation. Whether FMD has a role in detecting restenosis after DES implantation is not known. Further studies evaluating its role in general and in high-risk patients for restenosis after DES implantation needs clarification.

Acknowledgment: The authors are thankful to Dr. Ziynet Çınar for her support in statistical analyzes.

Conflict of interest: The authors declare that they have no conflict of interest and the study was not funded by any source.

\section{REFERENCES}

1. Townsend N, Nichols M, Scarborough P, Rayner M. Cardiovascular disease in Europeepidemiological update 2015. Eur Heart J. 2015;36(40):2696-705.

2. Timmis A, Townsend N, Gale C, et al.; ESC Scientific Document Group. European Society of Cardiology: Cardiovascular Disease Statistics 2017. Eur Heart J. 2018;39(7):508-79.

3. Gimbrone MA Jr, García-Cardeña G. Endothelial Cell Dysfunction and the Pathobiology of Atherosclerosis. Circ Res. 2016;118(4):620-36.

4. Ross R. The pathogenesis of atherosclerosis: a perspective for the 1990s. Nature. 1993;362(6423):801-9.

5. Thijssen DHJ, Bruno RM, van Mil ACCM, et al. Expert consensus and evidence-based recommendations for the assessment of flow- mediated dilation in humans Eur Heart J. 2019;40(30):2534-47.

6. Ras RT, Streppel MT, Draijer R, Zock PL. Flow-mediated dilation and cardiovascular risk prediction: a systematic review with metaanalysis. Int J Cardiol. 2013;168(1):344-51.

7. Matsuzawa Y, Kwon TG, Lennon RJ, Lerman LO, Lerman A. Prognostic Value of FlowMediated Vasodilation in Brachial Artery and Fingertip Artery for Cardiovascular Events: A Systematic Review and Meta-Analysis. J Am Heart Assoc. 2015;4(11):e002270.

8. Xu Y, Arora RC, Hiebert BM, et al. Noninvasive endothelial function testing and the risk of adverse outcomes: a systematic review and meta-analysis. Eur Heart J Cardiovasc Imaging. 2014;15(7):736-46.

9. Green DJ, Jones H, Thijssen D, Cable NT, Atkinson G. Flow-mediated dilation and cardiovascular event prediction: does nitric oxide matter? Hypertension. 2011;57(3):363-9.

10.National Cholesterol Education Program (NCEP) Expert Panel on Detection, Evaluation, and Treatment of High Blood Cholesterol in Adults (Adult Treatment Panel III). Third Report of the National Cholesterol Education Program (NCEP) Expert Panel on Detection, Evaluation, and Treatment of High Blood Cholesterol in Adults (Adult Treatment Panel III) final report. Circulation. 2002;106(25):3143-421.

11. Kristian Thygesen; Joseph S. Alpert; Harvey D. White, on behalf of the Joint ESC/ACCF/AHA/WHF Task Force for the Redefinition of Myocardial Infarction. Universal Definition of Myocardial Infarction. Circulation. 2007;116(22):2634-53.

12.TIMI Study Group. The Thrombolysis in Myocardial Infarction (TIMI) trial. Phase I findings. $\mathrm{N}$ Engl J Med. 1985 Apr 4;312(14):932-6.

13.Libby PP, Bonow RO, Mann DL, Zipes DP. Braunwald's Heart Disease: A Textbook of Cardiovascular Medicine. 8th edition. Philadelphia: Elsevier Science, 2007:20:465500.

14.Gensini GG. Coronary arteriogaphy. Mount Kisco, New York: Futura Publishing Co, 1975.

15.Ellis SG, Vandormael MG, Cowley MJ, et al. Coronary morphologic and clinical determinants of procedural outcome with angioplasty for multivessel coronary disease. Implications for patient selection. Multivessel 
Angioplasty Prognosis Study Group. Circulation. 1990;82(4):1193-202.

16.Ross R. Atherosclerosis--an inflammatory disease. N Engl J Med. 1999;340(2):115-26.

17.Halcox JP, Quyyumi AA. Coronary vascular endothelial function and myocardial ischemia: why should we worry about endothelial dysfunction? Coron Artery Dis. 2001;12(6):475-84.

18. Perticone F, Ceravolo R, Pujia A, et al. Prognostic significance of endothelial dysfunction in hypertensive patients. Circulation. 2001;104(2):191-6.

19.Halcox JP, Schenke WH, Zalos G, et al. Prognostic value of coronary vascular endothelial dysfunction. Circulation. 2002;106(6):653-8.

20.Fichtlscherer S, Breuer S, Zeiher AM. Prognostic value of systemic endothelial dysfunction in patients with acute coronary syndromes: further evidence for the existence of the "vulnerable" patient. Circulation. 2004;110(14):1926-32.

21. Anderson TJ, Uehata A, Gerhard MD, et al. Close relation of endothelial function in the human coronary and peripheral circulations. J Am Coll Cardiol. 1995;26(5):1235-41.

22.Lau KK, Chan YH, Yiu KH, et al. Incremental predictive value of vascular assessments combined with the Framingham Risk Score for prediction of coronary events in subjects of lowintermediate risk. Postgrad Med J. 2008;84(989):153-7.

23.Patti G, Pasceri V, Melfi R, et al. Impaired flowmediated dilation and risk of restenosis in patients undergoing coronary stent implantation. Circulation. 2005;111(1):70-5.

24. Kitta Y, Nakamura T, Kodama Y, et al. Endothelial vasomotor dysfunction in the brachial artery is associated with late in-stent coronary restenosis. J Am Coll Cardiol. 2005;46(4):648-55.

25.Lowe HC, Oesterle SN, Khachigian LM. Coronary in-stent restenosis: current status and future strategies. J Am Coll Cardiol. 2002;39(2):183-93.
26. Rajagopal V, Rockson SG. Coronary restenosis: a review of mechanisms and management. Am J Med. 2003;115(7):547-53.

27.Wang G, Jacquet L, Karamariti E, Xu Q. Origin and differentiation of vascular smooth muscle cells. J Physiol. 2015;593(14):3013-30.

28.Bønaa KH, Mannsverk J, Wiseth $\mathrm{R}$, et al.; NORSTENT Investigators. Drug-Eluting or Bare-Metal Stents for Coronary Artery Disease. N Engl J Med. 2016;375(13):1242-52.

29.Kubo M, Miyoshi T, Oe H, et al. Prognostic significance of endothelial dysfunction in patients undergoing percutaneous coronary intervention in the era of drug-eluting stents. BMC Cardiovasc Disord. 2015;15:102.

30. Yamawaki T, Yamada A, Fukumoto Y, et al. Statin therapy may prevent restenosis after successful coronary intervention, independent of lipid-lowering effect and CRP level. Fukuoka Igaku Zasshi. 2007;98(6):260-9.

31. Yamamoto T, Takeda K, Harada S, et al. HMGCoA reductase inhibitor enhances inducible nitric oxide synthase expression in rat vascular smooth muscle cells; involvement of the Rho/Rho kinase pathway. Atherosclerosis. 2003;166(2):213-22.

32.Virdis A, Colucci R, Versari D, et al. Atorvastatin prevents endothelial dysfunction in mesenteric arteries from spontaneously hypertensive rats: role of cyclooxygenase 2derived contracting prostanoids. Hypertension. 2009;53(6):1008-16.

33.Simova II, Denchev SV, Dimitrov SI. Effects of statins on endothelial function in patients with coronary artery disease. Clin Cardiol. 2009;32(4):193-8.

34.Bae JH, Bassenge E, Kim KY, et al. Effects of low-dose atorvastatin on vascular responses in patients undergoing percutaneous coronary intervention with stenting. $\mathbf{J}$ Cardiovasc Pharmacol Ther. 2004;9(3):185-92.

35.Erl W, Hristov M, Neureuter M, et al. HMGCoA reductase inhibitors induce apoptosis in neointima-derived vascular smooth muscle cells. Atherosclerosis. 2003;169(2):251-8.

36.Erl W. Statin-induced vascular smooth muscle cell apoptosis: a possible role in the prevention of restenosis? Curr Drug Targets Cardiovasc Haematol Disord. 2005;5(2):135-44. 